\author{
Любинко Раденкович \\ Сербская академия наук и искусств \\ rljubink@eunet.rs \\ Ljubinko Radenković \\ Serbian Academy of Sciences and Arts \\ rljubink@eunet.rs
}

\title{
МИФОЛОГИЧЕСКИЕ ПЕРСОНАЖИ ДЛЯ УСТРАШЕНИЯ ДЕТЕЙ У СЛАВЯН
}

\section{SLAVIC MYTHOLOGICAL CHARACTERS FOR FRIGHTENING CHILDREN}

В статье, на материале этнографических и лексических источников, исследуется общее и региональное в наименовании мифологических персонажей для устрашения детей у славянских народов и, связанных с этим, предикатов. Обращается внимание и на разыгрывание ситуации устрашения, где взрослые наряжаются и принимают на себя роль мифологических персонажей. Кроме функции успокаивания, устрашения детей представляют собой один из механизмов культуры, посредством которого в обществе, у детей в раннем возрасте, устанавливались, как семантика пространства и времени, так и образцы желаемого социального поведения, а также и отношение ко всему чужому и потенциально опасному из окружающего мира.

Ключевые слова: страх, дети, мифологические персонажи, лексикология, народная культура славян.

The traditional raising of children among the Slavic peoples actively utilized frightening - among other things using mythological characters. These characters, unlike mythological beings, have minimal features. Most commonly their appearance is undefined and is not indicative of where they live and when they are active. The image is created that they are always near the child and always prepared to punish it if it is disobedient. According to this study, the language and folklore of the Slavic people contains no less than 200 such characters. In this function, on one hand, they overlap with certain animals (most commonly the bear, wolf and bugs) and foreigners (Gypries, Turks, Tatars), and on the other with mythological beings (rusalka, vodyanoy, house spirit, devil). In addition to its function of pacifying children, frightening represents one of the cultural mechanisms that at an early age impose on children the semantics of space and time, as well as desirable forms of social conduct.

Key words: fear, children, mythological characters, lexicology, Slavic folk culture. 
В воспитании детей у всех славян активно использовались и устрашения. В бытовой речи и в колыбельных песнях существует особая группа персонажей - страшилок, служащих только для устрашения детей. По исследованиям Головина, мифологических персонажей в русских колыбельных песен, в основном, только пять (Бука, Бабай/Бабайка/Басалай/Maмай, Угоман и Сон-Дрема), все остальные являются их вариантами (Головин 2000: 215). В бытовой речи, судя по славянским фольклорным записям и региональным словарям, их значительно больше - около двухсот. Эти персонажи обладают минимальными признаками. Чаще всего имеют неопределенную внешность, иногда без указаний, где они пребывают, а их основная функция - готовность в любой момент схватить и унести с собой непослушного ребенка: «У! У! Хам-те ... баба-то яга, схватит, подико, поди... вот она, тут и есть за дверями» (Даль 1996: 166). Они смыкаются, с одной стороны, с определенными животными (чаще всего с медведем и волком) и с чужими людьми (цыганами, турками, немцами, татарами и другими), a с другой, с мифологическими существами, такими как: русалка, леший, водяной, черт. Первоначальное значение многих из них забыто, о чем свидетельствуют и информанты из России (Псковская область), белорусскоукраинского Полесья и Сербии (Суботица): «В ёвну (овин) не ходите: в ёвне матуз. А какой той матуз - Бог его знаеть» (Ивлева 2004: 215); «Все лякали барабушей, я ії сама не знаю, шо за барабуша (Буйских 2014: 37); «Знам да смо плашили децу, ено иде бубущ, ал' што је бубуш, никад не знам шта је бубуш» (Знаю, что мы пугали детей, вот идет бубуи, но что такое бубуш, никогда не знал, что такое бубуш) (РСГВ 2000/1: 148). Страшилище, которым пугают детей - бирюк, в некоторых районах России обозначает волка или медведя, на Дону - домового (Власова 1998: 48), в Орловской губернии еще и одинокого, нелюдимого человека. Известное страшилище у русских бабай, тоже многозначное. Понимается оно то как существо наподобие домового, то как молчаливый, замкнутый человек (Леонтьева 2017: 242).

Для непослушного ребенка в хорватском озальском говоре существует название нестрах (Težak 1981: 401), т. е. «тот, который ничего не боится».

\section{Обшее и региональное}

Общим во всех славянских языках являются названия действия устрашения: ст. слав. страшити, рус. страшить, сербо-хорватско-словен. сииращиитии, болг. страма, чеш. strašiti, польск. straszić (производное от праслав. *strahb); рус. полошить, ст. слав. полошити, сербо-хорватско-словен. йлащиити и, болг. плама, чеш. plašiti, польск. płoszyć (от праслав. *polhъ, *polšiti); pус. пугать/пужать представляет собой новообразование от пудить, ст. слав. поудити, сербо-хорв. $\bar{u} y \partial u \bar{u} u$, словен. poditi, чеш. puditi, польск. pędzić «гнать, пугать». Новообразованием можно считать и рус. диал. лякать «пугать» (ляка «пугало, страшилище»), укр. лякати, бел. (полес.) лекаты, поль. lękać się «бояться», сербо-хорв. леинуйи се «пугаться», от праслав. *lęk«гнуть». 


\section{Наименования мифологических персонажей}

Между собранных более 200 наименований персонажей для устрашения детей у всех славянских народов можно обнаружить, что только названия формированные из основы *ba-/*bo-/*bu-, или с корнем *bab-, *bob-, *bub- являются общими. Все остальные, более или менее, имеют региональное распространение.

Центральным из этих мифологических образов, известный на широкой территории в России, является бука: «Спи, спи, бука идет!»; «Не шуми, сейчас бука придет!» (Черепанова 1983: 115-121; Черепанова 1994: 25; Хафизова 2000: 198-211). На Украине и в Белоруссии редко встречаются устрашения детей букой. Но, из восточнославянских названий устрашителей только это имеет распространение и на Балканах, конкретно в сербских говорах в Герцеговине, в юго-западной Сербии и в Косово: «Шути, ето буке!» (Молчи, бука идет!) (Грђић Бјелокосић б. г.: 128); «Спавај, има бука!» (Спи, там бука!) (с. Рудно, юго-западная Сербия). В Косово, когда мать решает перестать кормить ребенка грудью, кладет на грудь шкуру зайца или овечью шерсть и показывая ему, говорит: «Ете, баја, бука!» (Вот, бая, бука!) (Вукановић 2001: 315).

Бука имеет весьма расплывчатый образ. Лохматый бука может быть сходен с медведем и с ряженым в шубе наизнанику, связывается с мифологическими существами - лешим, домовым, водяным, банником; букой называли даже большое черное пятно сажи или пучок можжевельника под матицей. Функции буки ограничены - он, кажется, способен только пугать. Он не ест, не душит, не щекочет до смерти, не топит, не уводит неизвестно куда, только грозит. Не нашлось ни одного текста былички, где бука исполняет свою угрозу (Головин 2000: 218).

Вариантные названия буки у русских на Урале являются: букареи, букарииа, буканай, букашко, буканко (Востриков 2000: 144-150), в Архангельской губ. буван: «Спи, спи! А то вот буван придет к окошку ... и сволокет тебя к цыганам» (Власова 1998: 55), в Нижегородской области - букан, буканка, бубука (Любова 2015: 307). В хорватском брушском говоре зафиксировано название детского пугала bukanace (Dulčić 1985: 394), на острове Крк на Адриатике - bučan (Milčetić 1896: 227).

У поляков и чехов, наряду с babok, babuk, кажется, преобладают названия с корнем *bob-/*bub-: поль. bobo, bobon, bobak, bubka, bobuk, bobuška, bubak, bubbul (Podgórscy 2005: 53); чеш. bobo, buba, bubač, bubača, bubaček, bubak, bubaraš (Зайцева 1975: 213, 216); в в.луж. bubak, bobak, Bubu-mann, Bubamann (Сятковский 1998/I: 280), у белорусов — бабар; у хорватов бабуко; сербов (Банат) - бабау (РСГВ 2000/1: 64), (Косово) баучка (Елезовић 1932/I: 34). Название страшилища буба является в болгарском, македонском, сербском и хорватском (кайкавский диалект) языках (основное значение слова «жук»). В этот круг страшилок входит и сербо-хорв. bubuš (РСГВ 2000/1: 148). 
У сербов самое известное страшилище - баук (Петровић 1933: 104107), в западной Сербии (Ужице) и Метохији баја, бајук (Цвијетић 2014: 29, Букумирић 2012: 28), баро (РСАНУ 1959/I: 312), у македонцев - бауч и баубау (РМЈ 1986: 23), у черногорцев - барек/ бареч - «Бјеж, ето барека!» (Убегай, барек идет!) (Копривица 2006: 28), «Бљеж, ето бареча из лијесака!» (Убегай, вот бареч из леса!) (Гаговић 2004: 15); словенцев (Доленьска) bauc (Kropej 2008: 314), bavec (Weiss 1998: 85), bavbav «Če ne boš priden, te bo vzel bavbav!» (Не будешь хорошо себя вести, бавбав тебя заберет!) (Јurančič 1981: 70), хорватов — bav-bav (Božićević 1906: 90); bavec «Bu te bavec! Bavec ide!» (Смотри бавец! Бавец идет!) (Lang 1914: 306), болгар - бах «Кажи бахъ! да го уплашишь» (Скажи бах!, чтобы испугать его) (Геров 1975/I: 28), и т. д.

\section{Мифологические дед и баба (бабушка) как страшилки}

Большая группа персонажей для устрашения детей строится по признаку молодой/старыц̆, где устрашители связываются со вторым членом этого противопоставления. Они могут пониматься как чужие, реально существующие люди, но очень часто имеют и дополнительные мифологические признаки. Так, на Русском Севере (Архангельская область) встречается выражение: «Старик в котомку посадит, не реви!» В Рязанской области: «Не ори, а то старик лохматый идет!» (Ивлева 2004: 209, 164); у поляков «Dziad weżmie!» (Дед возьмет!) (Podgórscy 2005: 173). С другой стороны, в формулах фигурируют: дед Бабай — «Замолчи! А то дед Бабай с мешком сейчас придет и заберет. Отнесет за кустик и назад не пустит» (Науменко 1998: 157) и страшилище Мамай, которое у русских понимается как существо в облике страшного незнакомца, старика с палкой (Власова 1998: 26, 328). В Ульяновском Присурии, детей страшат шайтаном, дедушкой нехорошим: «Вот шайтан там, шшикатун да дедушка нихароший, вот эдаки!» (Морозов, Слепцова 2012: 422). Упоминаются еще дед Сятковской - «Э, Э, будишь вольничать, а там дед Сятковской щас вылезеть!» (Власова, Жекулина 2001: 243); дед-бородей — «Дед-бородей в колодези!» (Ивлева 2004: 215); у белорусов Pусавы дзед — «Не лезце, дзетки, у жыта Русавы дзед ухопіць!» (Цыхун 2011: 408); у болгар д’ивийа старец — «Старый, уродливый человек с большим мешком, крадущий детей; живет в горах» (Узенева 2004: 293). В виде старика с косматыми руками Словенцы в Штирии детям представляли страшилище под названием мук: «Ne hodi $\mathrm{k}$ mlaki, da te Muk notri ne potegne! (Не подходи к луже, а то Мук утянет!) (Majciger 1883: 560).

По количеству наименований преобладают женские мифологические персонажи с корнем *bab- . У сербов и хорватов широко известна бабарога: «Spavaj, jel sa' će te odnet babaroga!» (Спи, а то сейчас унесет баба рога!) (Peić, Bačlija 1990: 22); в восточной Сербии «Сьд че доџе караконџа и баба Рога, има да ви уједу» (Сейчас придут караконджа и баба Рога, и укусят 
вас) (Плотникова 2004: 134); «Немој да викаш, че дојде баба Рога да те однесе и изеде. Има да те однесе у џак» (Не плачь, а то придет баба Рога, унесет тебя и съест. Утащит она тебя в мешке) (Златковић 1989: 296). Это детское стршилище у сербов понимается как страшная рогатая бабушка. У хорватов «это высокая и худая женщина, одетая в черное платье - черная и сухая как старая кость» (Било-гора) (Lovrenčević 1969-70: 92-93); или «имеет большую голову, зубы как у коня, выпученные глаза, высокая, худая, сгорбленная» (западная Славония) (Nožinić 1988). Наверное, бабарога когда-то имела функцию устрашения детей, чтобы они не ходили в поле под злаками. Такая функция бабароги сохранилась у хорватов (Кутина) (Nožinić 1989). У чехов такой дух называется žitná bába (Зайцева 1975: 280). Детям в Германии, желающим собирать в поле голубые васильки или маки, запрещали делать это, потому что там их могла схватить Мать Зерна, или Мать Ржи (Фрэзер1980: 442-443). На Русском Севере пугали детей кудельницей и полуднищей, чтобы в рожь не ходили: «Подьте в рожь, там кудельница захватит резиновыми клещиками» (Черепанова 1983: 113), «Там в рже полудница сидит» (Левкиевская 2001: 461). У белорусов, в Полесье, чтобы дети не ходили в житные поля, их страшили смолянкой (то же самое, что и русалка) «Нейди, бо ужэ вечор, нейди у жыто, бо там смулянки» (Левкиевская 2001: 422), в Вилейском районе белой бабой: «Не ідзі ў жыта, там белая баба!» (Авілін и др. 2016: 243). В западной Украине, чтобы дети не ходили в горох, пугали их дикой бабой, которая якобы ударит их макогоном по спине, или утащит: «там дика баба стойит з дзелїзним макогоном: як лусне котре по хребтї, то лише цяпне» (Колесса 1898: 94). На Урале, в этой функции является огородная бабушка. «Бабушка огородна словит, не ходите в огород, она в борозде сидит» (Востриков 2000: 151).

Сказочный персонаж - Баба Яга, имеет и функцию устрашителя детей у русских и белорусов. Детей пугали, чтобы не подходили к колодцу, не лазили в огород, не ходили купаться. В Полесье говорили: «Не заглядай ў колодец, бо там баба яга сидить» (Левкиевская 2001: 381). В Рязанской области детей пугали: «Баба Яга костяная нога тебя унесет, старик заберет!» (Ивлева 2004: 99). В Сумской области детям говорили: «Баба Яга вон ездит с кавошею, кашель такой, на коляске. Хто капризничаеть, так повязеть тебя с коляскою в лес» (Чеха 2005: 34). В одной записи из Смоленской области формула запугивания с Бабой Ягой даже имеет форму песенки: «Не реви! А то Баба Яга - старая карга придет, тебя отнесет в лесок и зароет во песок. А медведи найдут, на тебя заревут. Кабаны придут, под дубок отнесут. Будешь под дубком лежать, будут птички прилетать, тебе кушать не давать. Не будешь расти и помрешь в напасти! Ну, замолчи, не реви! Вон Бабка Яга - порота нога за дверьми стоит, на тебя глядит. Поди - поди, Бабка Яга, сюда! Алешка-то не затихает!» (Науменко 1998: 156). В Архангельской области наподобие Бабы Яги является устрашитель жихонюшка: «Жихонюшка придет и заберет!» (Дранникова, Разумова 2009: 130). 
У словенцев детей, которые не постятся и плохо себя ведут, пугали календарным демоном, страшной бабушкой перхтой (perhta) (Kelemina 1997: 94), в Бохине пехтой (pehta): «Te bo Pehta, č' naš pamet'n» (Cvetek 1993: $36,37)$, у чехов и словаков перихтой, nерухтой (perichta, peruchta) (Зайцева 1975: 250, 251). Такую же функцию имеет и баба Кокорача (Корача) и баба Коризма у черногорцев (РСАНУ 1978/Х: 237; Драговић 1997: 217). У словенцев в Прекмурю детей страшали бабой торклей «С̆е nete vrli, pride baba Torkla po vas, vas odvleče v mürsko šumo pa vas tan pojej!» (Если не будете хорошими, придет бабушка Торкла, и утянет вас в мурский лес и съест она вас там) и бабой чамрой «Stara baba Čamra prijde po vas pa vas odvleče v Čaren loug, vas na žarečem ognji speče pa vas poje» (Придет старая бабушка Чамра и утянет вас в Черную рощу, на разожженном огне поджарит и съест) (Rešek 1995: 52, 54). Матери в Истрии, когда отправлялись на рынок в Триесте, чтобы дети не требовали ходить с ними, пугали их имркавой бабой (šmrkava baba), т. е. сопливой бабушкой (Hrobat 2008: 411-414). У белорусов детей устрашали железной бабой (баба зелизна): «Баба зелизна сэдыть» (Левкиевская 2001: 380); «Не дивись во колодец, там баба железна» (Виноградова, Левкиевская 2012/II: 687), также и голобабой (Валодзіна 2011: 121). На Русском Севере детей пугали бабкой Марой: «Куда побежал, вот там бабка Мара!» (Черепанова 1994: 25; Черепанова 1983: 26); «Сицяс Мара забирет — вот там на вышке!» (Смольников 1996: 51), так же и байной старухой: «Какая байная старуха!» (Левкиевская 2001: 432); жихарь-бабкой: «Жихарь-бабка, выдь с лопаткой, дай справодку!» (Дранникова, Разумова 2019: 79). Одним из фантастических существ, которым у русских пугали детей, является и старуха бабайка (Власова 1998: 26).

В западной Сербии детей страшили бабой Гогой (баба Гога) (Цвијетић 2014: 28). В южной Сербии, в окрестностях Лесковца, гогами называли вид устрашения детей имитацией голосов животных, которые как будто ищут ребенка, потому что он плачет. Говорили: «Дајте ми тој дете што плаче, дајте!» (Отдайте мне этого ребенка, который плачет, отдайте!) (Ђорђевић 1958: 155). В Банате (Вршац), у сербов, болгар и румынов, гога, одно из наименований для устрашения детей: «Ајде, спавај, јер са(д) ће да дође гога да те однесе» (Давай, спи, а то сейчас придёт гога и утащит тебя) (РСГВ 2002/2: 152; Стойков 1968: 59). Страшилище gogë, gogol встречается и у албанцев (Дукова 2015: 160). Одно из названий уыпря у болгар - гогош (БЕР 1971/I: 259). В Косово (Призрен) гогами называли волохов (РСАНУ 1965/ III: 413).

В сербской области Левач и Темнич девочкам, если они не хотят вязать, матери грозили, что им баба клупчара растолочет пальцы в ступе, а если не хотят прясть, баба предара сожжет им пальцы и волосы на голове (Мијатовић, Бушетић 1925: 146). В Воеводине (Срем), детей, особенно молодых прях, пугали бабушкой с железными зубами - гвоздензубой. Говорили, что она носит с собой кастрюлю с горячим углем и, если они не будут хорошо прясть, она им сожжет пальцы (Караџић 1986/I: 139). В этой же области Сербии гвоздензубой детей страшили и в других слу- 
чаях: «Зваћу гвоздензубу ако не будеш добар» (Позову гвоздензубу, если не будешь хорошо себя вести) (РСГВ 2002/2: 129). Как устрашители встречаются и другие мифологические бабушки - у карашеваков (славянское население в Румынии) - баба Кука и баба Рока (Радан 2002: 143), у болгар (Варненская область) тарамбаба, (говорили, что она детей заберает в мешок), баба Гълта (она детей проглотит, если они будут баловаться у воды или у колодцев) (Седакова 2004: 264), баба крива (Врачанско); у хорватов баба Уjда (baba Ujda), баба зелявища (baba Zeljavica) (Jurić-Arambašić 2000: 403), крвава баба (krvava baba) (Nožinić 1986), в Истрии лела (РСАНУ 1981/ XI: 323).

Кроме «забрать» и «унести», характерные предикаты, связанные с мифологическими бабушками устрашителями детей, еще и съедать, глотать, толочь в ступе, бросать в яму, жарить. Так, у белорусов, железную бабу представляют как злую старуху, невысокого роста, с большой грудью, которая хватает крюком детей, если они одни окажутся в поле или в огороде с бобом или горохом, бросает их в свою железную ступу, толчет и съедает (Романов 1912: 290). У украинцев детям говорили, что залізная баба находится в колодце «як станеш у холодну воду - задубіеш і зробишся залізний» (Боряк 2006: 127-128). По рассказам из Герцеговины, кучибаба страшная горбатая старуха. Она носит с собой два мешка, в которые собирает детей, если они ночью выходят из дома и бросает их в какую-то яму (Грђић Бјелокосић б. г.: 203).

\section{Устрашения детей Богом и святыми}

Детей редко страшили Богом. Считалось неуместным «поднимать» силу Бога на маленьких детей. В Дубровнике, если ребенку грозили Богом, то он в этом случае именовался уменьшительно - «Боже»: «Кастигаће те Боже ако не будеш добар!» (Накажет тебя Боже, если не будешь послушным!) (Бојанић, Тривунац 2002: 48). В северо-восточной Сербии (Хомоле), один из видов отказа ребенку дальше сосать грудь у матери состоит в том, что мать красит грудь в красное и потом пугает ребенка, говоря, что Бог ей отрезал грудь (Милосављевић 1914: 113).

Так как было запрещено резать овощи в день Ивана Крестителя (Головосек), детей в этот день не пускали в огород, и если бы они пошли туда, то в Архангельской области их пугали: «Иван Постной голову отрежет» (Мороз 2009: 70), на Урале «Не ходите, сёдни Иван-капустник голову отсекёт! (Востриков 2000/5: 151).

На Русском Севере в святки детей пугали святой Варварой, говоря, что она в эти дни ходит со сковородкой (Черепанова 1983: 38).

\section{Реально существуюшие люди как устрашители}

Из реально существующих людей, у славян, широко известные запугивания детей «чужаками», т. е. социально-маркироваными лицами - 
цุыганом, попом, нищим, уродливым человеком или каким-нибудь опаснымм человеком из своей среды, или просто чужими людьми.

С образом цзыган связаны представления: они крадут, обманывают, занимаются гаданием и всяким другим мошенничеством, они черные, имеют нечеловеческий запах, т. е. они нечистые (ср. Белова 2012/5: 493-497). Есть и верование, что они могут украсть любого ребенка, который не под присмотром старших, чтобы для них просил милостыню. Оттуда и формула запугивания детей: «Цыган заберет, унесет!», ср. в окрестностях Каргополя: «Цыган тебя унесет!», «Цыган утащит!», «Отойди, цыган!» Кроме того, постоянный внешний признак цыганов это сума (мешок), средство которое часто встречается и в других формулах устрашения: у белорусов Полесья «дытыну лякалы, скажуть цыган, жыд забырэ, в торбыю дід чы баба забырэ, в торбу, в мышок» (Климчук 1995: 364). У сербов (южная Сербия, Лесковац) если дети в доме слишком шумят, говорили, что «цыганка их унесет в мешке и съест» (Ђорђевић 1958: 155); в юго-западной Сербии (Рудно): «Не иди тамо, иду Цигани отуд, туриће те у бакрач» (Не ходи туда, оттуда идут цыгане, засунут тебя в котел). У словенцев пугали детей: «Otruoci, bejšte, bejšte, grejuo cigani!» (Дети бегите, бегите, идут цыгане!); «Če ne boš priden, te bojuo vzijeli cigani!» (Если не будешь себя хорошо вести, заберут цыгане) (Keršovan, Krebelj 2003: 170).

Русские старообрядцы в Латвии пугали своих детей латышом: «Не плачьте, не делайте плохого, а то дядька-латыш придет в красной шубе и накажет вас» (Амосова, Гехт 2012: 59). В отличие от русских, латыши всегда красили свои шубы.

Когда детей пугают знакомым местным дурачком, калекой, пьяницей, опасным человеком, часто в формулах запугивания указывается, что он ребенка унесет в суме, ср. серб. (Шумадия, с. Коштуничи) «Ја сам плашила децу неким пијаним и хромим Баћом: - Ево Баће, сад ће да вас стави у џак и да вас однесе» (Я пугала детей каким-то пяным и хромым Батеем: - Вот Батя, сейчас он вас заберет в мешок и унесет); в восточной Сербии (Пирот) — «Ене, човек сас џакот, збира деца која викају» (Вон, человек с мешком, собирает детей, которые кричат) (Златковић 1989: 373); (Црна Трава) «Һут, немој ники да-е прозборил, ете га Симча из Дикаву с коња, ће ви однесе у џак» (Молчите, чтобы никто ни слово не вымолвил, вот Симча из Дикавы с конем, унесет вас в мешке) (Стојановић 2010: 950); в юго-западной Серби (Рудно) -«Еве иде Живојин (мутави просјак), носи торбе, ће ви однесе» (Вот идет Живоин - немой нищий, несет сумки, вас унесет). У болгар страшилище тарамбаба идет с мешком. На Русском Севере детей пугали чиликунамы. Говорили, что на Игнатьев день они из проруби вышли, и что у них на голове мешок (Черепанова 1996: 62). У хорватов мешок имеет мифологическое существо мрак: «Ето мрака, стрпаће те у мјешину!» (Вон мрак, он тебя в мешок засунет!) (РСАНУ 1988/XIII: 129). О постоянном месте мешка/сумки в формулах запугивания свидетельствуют и неологизмы, в основе которых лексемы «сумка», «торба», заменяющие имя 
собственное «страшного» человека, ср. у русских: «Ой, Сумач идет и маненьких собирает» (Рязанская область) (Ивлева 2004: 164). У болгар дядо турбалан (Верхная Тракия) представляет собой маленького человека с большим мешком, в который он сажает детей (Трефилова 2012: 278).

Эмоциональная реакция на появление чужих людей представляет важный этап в развитии ребенка. «Умение видеть, различать чужих, незнакомых людей - необходимое условие освоения ребенком социального пространства» (Чередникова 2002: 172).

\section{Устрашения с попом}

У русских и сербов, чтобы дети соблюдали пост, их устрашали попом: рус. «Поп уши отрежет!», «Поп уши обрежет» (Каргополь); серб. «һе ти исече поп уши што блажиш!» (Поп тебе отрежет уши, потому что ты ешь скоромное) (Лесковац; Ђорђевић 1958: 155); «Деца, нема да блажите, попат че ви одреже ушити» (Дети, нельзя вам есть скоромное, поп вам отрежет уши) (Пирот; Златковић 1989: 396); «Поп кида азик!» (Поп рвет язык) (сербы-черногорцы в Враке, Албания; Марковић 1981: 201). В юго-западной Сербии (Рудно) говорили «Ако не будеш постио, поп има маказе и сече језик» (Если не будешь поститься, у попа ножницы, ими язык отрежет).

В сербской области Срем (с. Оролик), детей пугали попом, если они между собой матерно ругались: говорили, что поп всегда с собой носит острый ножик и отрежет им язык (Бабовић 1963: 71).

\section{Разыгрывание ситуации устрашения детей}

Чтобы дети из огорода не ели горох или вечером не ходили на речку, для большей убедительности, старшие иногда наряжались в определенные мифологические существа и разыгрывали сценки, представляющие ситуацию страшного события: «А вот мы овчину, значит, ну, да в шубы, завернёмся, в борозду лягем, а они побегут, ребята-то: - Ой, там у нас полуден$\kappa a$ в огороде, мама» (Калинино Кунгурский район) (Подюков 2010: 337). В свердловской области мифологический персонаж, которым пугали детей, чтобы не лазали по огородам, называется бухмет. Там тоже одевали шубу и таким образом изображали его: « ... пойдем в огород, а там шуба в борозде, девки кричат: - Смотри, бухмет!» (Леонтьева 2017: 242); или, накинув шубу, наряжались косматым чудищем и, как-будто вылезая из воды, говорили ребенку: «Смотри, вылезит бабушка Яга, ана тибя схватит и на Суру утащит в воду! » (Морозов, Слепцова 2012/2: 423). На Урале, наряжались опалихой и пугали детей, чтобы те не ели бобы в огороде. Говорили, что это ведьма, которая живет в пруду, с длинными волосами и чугунной сковородкой, охраняющая огород: «Сидели однажды вдвоем с товарищем у нас на огороде, грызли бобы. Вдруг видим, что идет что-то волосатое с клюкой и прямо на нас. Так у меня с того времени порок сердца образовался, а то- 
варищ стал заикаться и до сих пор заикается. А это напугала нас моя сестра» (Кругляшева 1991: 228). В Нижегородском Поволжье, если дети долго купаются и не возвращаются домой, бабушка наряжается русалкой и идет их пугать: «Распущу, бывало, косы, одену белый халат, посошок возьму да бегу за ними. Они от меня, плачут. Внучонок домой прибежит: Мамка, за нами русалка гналась, с посошком!» (Корепова и др. 2007: 105). Иногда кто-то из домочадцев наряжался в образ знакомого дурачка и так пугал детей; «У нас мама сама нарижалась. Надела чапан и вот ана пашла вдоль Суры-ти: - Муся идет, Муся идет! Это был глупенький» (Морозов, Слепцова 2012: 423).

В Хорватии родители в течение года пугали детей, что на Николин день в дом придут св. Николай и Крампус (черт) и непослушных детей накажут, а послушным, которые умеют молиться, дадут награду. Вечером, накануне св. Николая, ходили ряженые, как правило, представляющие собой три персонажа - св. Николая (с искусственной бородой, в епископской одежде, с высокой бумажной шапкой на голове, а в руках с посохом и книгой с карандашом), ангела (в белой одежде, с бумажными крыльями, с корзиной с сахаром и подарками в одной руке, а в другой - с прутом) и черта - Крампуса (рогатый, одетый в черное, с красной шапкой на голове, в руках — цепи, на плечах — большая корзина). Перед домом, Крампус начинал звенеть цепями. Первый в дом входил «св. Николай» и спрашивал, кто из детей добрый и послушный и кто умеет молится, и его записывал в епископскую книжку и давал ему подарки. Между тем, непослушного ребенка Крампус обматывал цепями, клал в большую корзину и выносил на улицу. Если ребенок ему обещал, что будет добрым, он пускал его вернутся в дом. Детей, которые не умели молиться «ангел» хлестал прутом (Horvat 1896, 244-245). У чехов (моравцев) накануне св. Николая (sv. Mikulaš, 6. XII) ходил наказывать непослушных детей ряженый чертом - Кромпус. Он одет в вывернутый кожух до земли и подпоясан цепью. В восточной Словакии этот ряженый персонаж называется Крампус и он ходил вместе с Микулашем (Валенцова 2016: 122, 336). У словенцев в тот же день (словен. sv. Miklavž), но и после того дня, ходили ряженые по домам и дарили детям подарки или устрашали их. Между ними выделялись персонажи Миклавж и черт паркель (икратник, шкратель, худобец) (Kuret 1998/II: 220-242). В словенской области Белой краины, parkl ходил подпоясан цепью с вилами в руках. По свидетельству, некоторые дети, подвергнутые устрашению паркла всю жизнь заикались или болели эпилепсией (Kure 2004: 93).

У болгар (Странджа) детей страшили междероком, представляющим собой, как говорили, черное волосатое существо с четырьмя глазами, которое бродит ночью, ловит детей и съедает их. Там сами дети наряжались междероком: чернили лица и одевали одежду наизнанку (Георгиева 1993: 209). В северной Чехии и Моравии обходили дома ряженые под именем nерхты / шперехты и грозили детям, которые не постятся или не хотят мо- 
литься. Стучали в дверь и, держа веретено в руках, говорили, что они (плохим детям) распарывают или провертывают живот, «выметают» гусиным крылом, кладут туда солому и зашивают (Валенцова 2016: 224).

\section{Формуль запугивания детей}

Общими являются формулы запугивания детей, состоящие из запретительной части - спи, молчи, не шуми, не реви, не плачь, не ходи в огород, не купайся и указания на опасные последствия в случае несоблюдения этого запрета. Кроме защекотать, которое относится, как правило, только на устрашение русалками («Ня ходитя, а то тама вопилка или покликушка, оны защекотют» (Ивлева 2004: 109), все остальные предикаты указывают, что ребенок будет силой унесен из своего пространства в чужое (в болото, в реку, в лес, в колодец, в яму). Некоторые формулы более экспресивны: тут ребенку грозят, что мифологический персонаж съест его, или проглотит, будет толочь в ступе, жарить, бросит в яму.

Предикаты выражающие последствия несоблюдения запрета: $y m a-$ щичть/хватить/захватить/ухопить/сиапать/поймать/забрать/утягать. Рус. «Смотри, вон тя дедушка домовой утащит!»; «Пойдешь на реку чертовка утащит»; «Не ходите купаться, а то лешенька схватит!» (Корепова и др. 2007: 54, 101, 86); «Старухи нас, бывало, вечером на святках не пушшают идти: - Шулюганы уташут!» (Виноградов 2009: 131); «Не дури, коке отдам!», «Смотри, кукан в болота утащит!» «Хохла-мохря идет, скажешь, спи батюшко, а то унесет» (Власова 1998: 242, 273, 522); «Не купайся, тебя бухмариха уташшит!»; «В огород-от не бегай, полудница утащит!» «В огород не ходи, ягарма схватит!» «Не ходите в лес, там росомага вас поймает!» (Востриков 2000: 151-152); «Не шали, а то кулешменцы тебя утащат, ездат на шкуре, так увезут тебя!» (Синица 2010: 44); «Не хади в лес (или там куды, не ухади), а то там леший ходит, вас утащут!»; «Ни хади! Там мярун! Уташшит в Суру!» (Морозов, Слепцова 2012: 422, 423); «Егибова придет, возьмет, уташшит!» (Синица 2014: 58); «Если слушаться не будешь, водиной заберет, будет на тибе воду возить” (Любова 2015: 307); «Не реви, бадяй заберет!» (Черепанова 1994: 24); «Не реви, бабай заберет!» (Власова 1998: 26); «Коли будешь баловаться, маруха забяреть», «Там лизун сидить и утянеть» (Ивлева 2004: 237); «Не плач, а то мума возьме!» (Леонтьева 2017: 241), укр. «Ни плач, бо зара драб прейде і забира» (Хобзей 2002: 87), поль. «Nie chodź w żyto, bo cię zagacz schyta!" (Podgórscy 2005: 523-524); чеш. мор. »Nechod' ven, chytne t’a Maga» (Не ходи на улицу, схватит тебя Мага) (Валенцова 2018: 244); серб. «Пази да те у башти не ухвати татангрк!» (РСГВ 2009/9: 24); «Не иди тамо, ухватиће те бобан!» (Бабовић 1963: 70); словен. «Ne hodite od doma, dokler bomo na planini drva sekali ali pa na rovtah kosili, ker bi utegnil priti divji mož Vouvel in vas odnesti v svojo duplo» «Bodi priden, sicer te odnese Berbara!» (Kelemina 1977: 200, 201), «Bodi priden, sicer te bo Berbara odnesla!» «Da te sumper zveme!» (Kropej 2008: 314, 329); «De pride škrat, 
škarifić, torka, vas pobere! (Merkù 1976: 292) «Bo pršov polsnjak, pa te bo vzev!» (Cvetek 1993: 37); «Vas bodo krive petnice odvlekle!» «Te ponese pirta!» «Pride duja baba, te ponese!» (Ivančič Kutin 2018: 137, 141); хорв. «Лела ће те побрати!» (РСАНУ 1981/XI: 323); болг. «Че те земе таласьм!» (Заберет тебя таласьм!) (Трефилова 2004: 393).

Съест - рус. «Вот банный съест тебя! Не балуй!» «Водяна в речке живет, купаться не побежишь, уташшит и съест» (Востриков 2000: 150, 153); «Вунтериха съест!» (Власова 1998: 124); «В лесу маканька живет: не ходи в лес, а то маканька съест»; «Там русалка сидить у кустах, унясеть и волосы вырьвет на головы, замучаеть и зъесть» (Ивлева 2004: 118, 220); «Бомка схамкает!»; «Хока там съест тебя!» (Белова 2016: 367); укр. гуц. «Ни плачти, діти, бо гаман вас ззіст» (Хобзей 2002: 87); серб. »Бау, бау... видиш сине, иде баучка, па ће да те изеде»; «Ено баучине сад ће те изести» (PCAНУ 1959/I: 338); «Ћутите, деца, немој да дође суља да ве удави» (Златановић 1998: 391); «Ако не будеш слушао, појешће те мракан» (РСГВ 2005/5: 92); серб. черн. «Пс! не плачи, буди мирно, појешће те бареч» (РСАНУ 1959/I: 305); «Изјешће те каранђолози!»; хорв. «Eto ti hajduka izjesti će te!» (Bogišić 1874: 608); словен. «С̆a nab’š pridn, bo bavc paršu pa te bo p’jedu» (Если хорош не будешь, придет бавц и съест тебя) (Weiss 1998: 85); «Vrbaua je bitje, ki živi v Kolpi in žre žlehtne otroke, ki ne ubogajo staršev in se preveč približajo Kolpi» (Primc 1997: 253) (Врбауа существо, которое живет в (реке) Купе и проглатывает шаловливых непослушных детей, которые слишком приближаются к Купе); болг. «Буба-та, та ще тя грабне та тя изяде!»; чеш. мор. «Počkaj, šak já t’a zavleču na vantroky, tam t’a uvé zežere» (Подожди, отведу тебя к желобу, там тебя уве съест) (Валенцова 2018: 248).

Очень часто, когда сама ситуация указывает на запретное действие, в формуле запугивания отсуствует первая часть, и она состоит только из упоминания мифологического существа, как будто оно прячется в подполье, в темном углу дома или недалеко от дома, или оно на пути в дом: рус. «Ой, там бука!», «Бородей там сидит!», «Смотри, бухмет!», «Хохламохря идет!»; «Это русалки, русалки!», «Никуда не ходи, там шулигины», «Шишига придет!», «Задериха придет!», «Рохля в подпполе!», «Там мосорага!», «Какой додон-от идет!», «Не ходи ночью в подпол — там корноухий!»; укр. «Хро, вова!»; серб. «Има бау, бау!», «Има букача!», «Ето буке!», «Тамо има баја!», «Иде бубуш!», «Ето бареча!», «Ето баџакуше!», «Ето мракана!», «Ето вадоче!», «Ето бјелоге!», «Ето карапанџ!!», «Еto kukuvede!»; болг. «Бухълакът иде!», «Иде марокъ-тъ!», «Ронджа проклета!»; «Мъри, таласьмо ша доди!», «Няма вече цица, има коко!»; хорв. «Eto mrakana!», «Doći će glođan!»; словен. «Pride prierte!»; «Pridejo krivapete!»; польск. «W stedni sedzy mumacz!», «Mumk přińze!».

Иногда в формуле указывается на внешний вид мифологического существа: «полуношник летит с железным носом» (Корепова и др. 2007: 86), «водяной какой-та ширстяной, в шерсти весь» (Морозов, Слепцова 2012: 422), «ходят раскудланые русавки с велизными ножами». 


\section{Некоторые выводы}

У славян существует общее представление о буке, известном страшилище для детей, сводимое на «черное, волосатое существо, которое может унести или проглотить ребенка». С другой стороны, группа персонажей с основой баб-, сводимая на значение «набухать», (cр. наименования по этой основе - «пучок шерсти», «хлоп снега», «гриб», «небольшое темное облачко» и т. д.), ассоциативно связывается как с букой, так и с кругом персонажей, связанных с мешком (дядо торбалан, цыган, бродяга). Таким образом, можно говорить об исходной ситуации устрашения детей, как угрозе вернуть их туда, откуда они пришли, т. е. в материнскую утробу, которая в мифологических представлениях связывается с потусторонним миром.

Кроме функции успокаивания, страшилки представляют собой и один из механизмов культуры, посредством которого в обществе, у детей в раннем детстве, устанавливалась семантика пространства и времени, укреплялись определенные общественные ценности, а также и отношение ко всему чужому и потенциально опасному из окружающего мира (cр. Раденковић 2000: 146-155).

\section{ЛИТЕРАТУРА}

Авілін Цімафей, Антропаў Мікалай, Боганева Алена. „Русалки: знешні выгляд“. Беларускі фальклор: матерыяль і даследаванні. Зборнік. Вып. 3. Мінск: Беларуская навука, 2016: 222-273.

Амосова Светлана, Гехт М. Б. „Материалы экспедиции к старообрядцам г. Прейли (Латвия)“. Живая старина 3/75 (2012).

Бабовић Глиша. „Оролик. Историја, живот и обичаји једног сремског села“. Срйски ейног̄рафски зборник LXXVI. Београд 1963.

Белова Ольга. „Цыган“. Славянские древности. Этнолингвистический словарь под общей редакиией Н. И. Толстого. Т. 5. Москва: Международные отношения, 2012: 493-497.

Белова Ольга. „Мифологические представления и поверья хутора Крымский Усть-Донецкого района Ростовской области“. Демонология и народные верования. Сборник научных статей. Москва: ГРЦРФ, 2016: 356-374.

БЕР. Български етимологичен речник І. София: БАН, 1971.

Бојанић Михаило, Тривунац Растислава. „Речник дубровачког говора“. Срйски дијалекійоломки зборник XLIX. Београд: САНУ, 2002.

Боряк Олена. Україна: етнокультурна мозаїка. Київ: Либідь, 2006.

Буйских Юлия. „Персонажи детских запугиваний в современных представлениях украинцев в Полесья“. Живая старина 1/81 (2014): 36-38.

Букумирић Милета. Речник гоовора северне Мейохије. Књ. 15. Београд: Институт за српски језик САНУ, 2012.

Валенцова Марина. „Перхта“. Славянские древности. Этнолингвистический словарь под редакиией Н. И. Толстого. Т. 4. Москва: Международные отношения, 2009: 18-20.

Валенцова Марина. Народный календарь чехов и словаков. Этнолингвистический аспект. Москва: Индрик, 2019.

Валенцова Марина. „Моравская и силезкая демонология в чешско-словацком культурном ареале“. Slavica Slovaca 52/2 (2017): 122-132.

Валенцова Марина. „Моравская демонологическая лексика“. Славянский альманах 1-2. Москва: Индрик, 2018: 234-260.

Валодзіна Тацяна. „Голобаба“. Міфалогія беларусаў. Энцыклапедычны слоўнік. Мінск, 2011. 
Виноградов Георгий. Этнография детства и русская народная культура в Сибири. Москва: Восточная литература РАН, 2009.

Виноградова Людмила, Левкиевская Елена. Народная демонология Полесья. Публикаииии текстов в записях 80-90-х гг. ХХ века. Т. II. Москва: Языки русской культуры, 2012.

Власова Марина. Русские суеверия. Энииклопедический словарь. Санкт-Петербург: Азбука, 1998.

Власова Марина, Жекулина Валентина. Традиционный фольклор Новгородской области: сказки, легенды, предания, былички, заговоры (по записям 1963-1999). Санкт-Петербург: Алетейя, 2001.

Востриков Олег. Традииионная. культура Урала: этноидеографический словарь русских говоров Свердловской области. Вып. 1-5. Екатеринбург: Свердловский областной Дом фольклора, 2000.

Вукановић Татомир. Енщиклойедија народног̄ живойа, обичаја и веровања у Срба на Косову и Мет̄охији. Београд: Војноиздавачки завод -VERZALpress, 2001.

Гаговић Светозар. „Из лексике Пиве (село Безује)“. Срйски дијалекеиолощки зборник LI. Београд: САНУ, 2004: 1-312.

Георгиева Иваничка. Българска народна митология. Второ преработено и допълнено издание. София: Наука и изкуство, 1993.

Геров Найден. Речник на българския език І. Фототипно издание. София: Български писател, 1975.

Головин Валентин. Русская кольбельная песня в фольклоре и литературе. Турку: А̊bo Akademi University Press, 2000.

Грђић Бјелокосић Лука. „Народно сујеверије“. Гласник Земаљског̄ музеја VIII. Сарајево: Земаљска штампарија, 1896.

Грђић Бјелокосић Лука. Из народа и о народу. Београд: Просвета, б. г.

Даль Владимир. О повериях, суевериях и предрассудках русского народа. Санкт-Петербург: Литера, 1996.

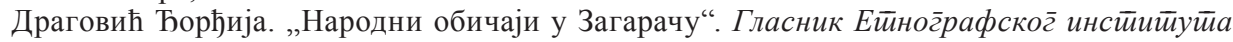
САНУ XLVI. Београд: САНУ, 1997: 195-220.

Дранникова Наталья, Разумова Ирина. Мифологические рассказы Архангельской области. Москва: ОГИ, 2009.

Дукова Уте. Наименования демонов в болгарском языке. Москва: Индрик, 2015.

Ђорђевић Драгутин. „Живот и обичаји народни у Лесковачкој Морави“. Срйски ейнографски зборник LXX. Београд: САНУ, 1958.

Елезовић Глиша. „Речник косовско-метохијског дијалекта“. Књ. І. Срйски дијалекӣолощки зборник IV. Београд, 1932.

Зайцева Н. И. Мифологическая лексика в чешском и словаиком языках. Диссертация. Минск: Белорусский университет, 1975.

Златановић Момчило. Речник гоовора јужне Србије. Врање: Учитељски факултет, 1998.

Златковић Драгољуб. „Фразеологија страха и наде у пиротском крају“. Срйски дијалекі̄олошки зборник XXXV. Београд: САНУ, 1989.

Ивлева Лариса. Представления восточных славян о нечистой силе и контактах с ней. Материалы полевой и архивной коллекции .... Составление В. Д. Кен. Санкт-Петербург: Петербургское востоковедение (Ethnographica Petropolitana, XIII), 2004.

Караџић Вук. Срииски рјечник (1852). I-II, Београд: Просвета, 1986.

Климчук Федор. „Духовная культура полесского села Симоновичи“. Славянский и балканский фольклор. Этнолингвистическое изучение Полесья. Москва: Индрик, 1995: 335 -364 .

Колесса Філярет. „Людові віруваня на Підгірю в с. Ходовичах Стрійського повіту“. Emнографічний збірник. T. V. Львів: Накладом Наук. Т-ва ім. Шевченка, 1898: 76-116.

Копривица Јован. Речник гоовора Бањана, Грахова и Ойуйних Рудина. Приредио Б. А. Копривица. Књ. 47. Подгорица: Црногорска академија наука и умјетности, 2006.

Корепова Клара, Храмова Наталья, Шеваренкова Юлия. Мифологические рассказы и поверья Нижегородского Поволжья. Санкт-Петербург: Тропа Троянова, 2007.

Кругляшева Вера (сост.) Предания и легенды Урала. Свердловск: Средне-Уральское книжное изд-во, 1991. 
Левкиевская Елена. „1) Демонология. Материалы к словарю полесской этнокультурной лексики; 2) Демонология севернорусского села Тихманьги“. Восточнославянский этнолингвистический сборник. Исследования и материалы. Москва: Индрик, 2001: 379-431, 432-476.

Леонтьева Татьяна. „К изучению семантических связей между наименованиями мифологических персонажей и характеристиками людей“. III Всероссийский конгресс фольклористов. Т. 1. Актуальные проблемы российской фольклористики. Москва: РОСКУЛЬТПРОЕКТ, 2017.

Любова Е. Ю. „Система мифологических представлений в говоре П. Сарма Вознесенского района Нижегородской области“". Вторые Громовские чтения. Русские народные говоры: прошлое и натоящее. Сборник материалов и исследований. Кострома: КГУ им. Н. А. Некрасова, 2015.

Марковић Благоје. „Фолклористички записи из Враке“. Прилози йроучавағу језика 17. Нови Сад: Филозофски факултет, 1981.

Мијатовић Станоје, Бушетић Тодор. „Технички радови Срба сељака у Левчу и Темнићу“. Срйски ейног̄рафски зборник XXXII, Београд 1925.

Милосављевић Сава. „Српски народни обичаји из среза хомољског“. Срйски ейног̄рафски зборник ХІХ. Београд: САНУ, 1914.

Мороз Андрей. Святые Русского Севера. Народная агиография. Москва: ОГИ, 2009.

Морозов Игорь, Слепцова Ирина. „Пугать“. Традиционная культура Ульяновского Присурья. Этнодиалектный словарь. Т. 2. Москва: Индрик, 2012: 419-430.

Науменко Георгий. Этнография детства. Сборник фольклорных и этнографических материалов. Беловодье - Москва: Российский союз любительских фольклорных ансамблей, 1998.

Петровић Петар. „О бауку“. Гласник Ее̄ног̄рафског̄ музеја VIII. Београд: Етнографски музеј, 1933: 104-107.

Плотникова Анна. „Мифологическая лексика сербско-болгарского пограничья“. Исследования по славянской диалектологии 10. Москва: Институт славяноведения РАН, 2004.

Подюков Иван. и др. Словарь русских говоров Южного Прикамья. Вып. II. Пермь: Издательство ПГГПУ, 2010.

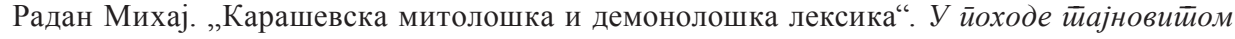
Каращу. Темишвар, 2002: 139 -158.

Раденковић Љубинко. „Страшила за децу - неке словенске паралеле“. Жизненият ииикъл. Доклади от българо-сръбска научна конференция. София: Етнографски институт с музей, 2000: 146-155.

РМЈ. Речник на македонскиот јазик со срйскохрватски толкуваґа. Редактор Блаже Конески. Скопје: Македонска книга, 1986.

Романов Евдоким. Белорусский сборник. Быт белорусса. Т. VIII. Вильна: Типография А. Г. Сыркина, 1912.

РСАНУ. Речник сриискохрват̄иског̄ къижевног̄ и народног̄ језика I-XXI. Београд: САНУ, 1959-2020.

РСГВ. Речник срйских г̄овора Војводине 1-10. Нови Сад: Матица српска, 2000-2010.

Седакова Ирина. „Этнолингвистические материалы из северо-восточной Болгарии (с. Равна, Варненская обл.)“. Исследования по славянской диалектологии 10. Москва: Институт славяноведения РАН, 2004.

Синица Н. А. „Лексика народной демонологии Павинского района“. Живая старина 3/67 (2010): 43-46.

Синица Н. А. „Демоническая лексика Никольского района Вологодской области“. Живая старина 3/83 (2014): 55-58.

Смольников С. Н. „Демонологические представления в Вашкинском р-не Вологодской области“. Живая старина 1/9 (1996): 50-51.

Стојановић Радосав. „Црнотравски речник“. Срйски дијалекӣолощки зборник LVII. Београд: Институт за српски језик САНУ, 2010.

Стойков Стойко. Лексиката на банатския говор, с банатско-български речник. София: БАН, 1968. 
Сятковский Януш. „Славянские названия страшилищ (демонов) в немецком языке и его говорах“. Слово и культура. Памяти Никиты Ильича Толстого. Т. І. Москва: Индрик, 1998: 280-287.

Трефилова Ольга. „Этнолингвистические материалы из с. Стакевцы, район г. Белоградчика (Северо-Западная Болгария)“. Исследования по славянской диалектологии 10. Москва: Институт славяноведения РАН, 2004: 354-398.

Трефилова Ольга. „Народная мифология из Твырдицы (Болгария, Верхняя Фракия)“. Карпато-балканский диалектный ландшафт. Язык и культура 2. Москва: Институт славяноведения РАН, 2012: 270-285.

Узенева Елена. „Этнолингвистические материалы из центральной Болгарии (село Дылбоки, область Старой Загоры)“. Исследования по славянской диалектологии 10. Москва: Институт славяноведения, 2004: 268-297.

Фрэзер Джеймс Джордж. Золотая ветвь: Исследование магии и религии. Москва: Политиздат, 1980.

Хафизова Лариса. „Бука как персонаж детского фольклора“. Славянский и балканский фольклор: народная демонология. Москва: Институт славяноведения РАН, 2000: 198-211.

Хобзей Наталя. Гуиульська міфологія: етнолінгвістичний словник. Львів: Інститут українознавства ім. І. Крип'якевича НАН України, 2002.

Цвијетић Ратомир. Речник ужичког̄ г̄овора. Београд: Службени гласник, 2014.

Цыхун Генадзь А. „Русавы дзед“. Міфологія беларусаў. Мінск, 2011.

Чередникова Маина. „Голос детства из дальней дали...“ (Игра, магия, миф в детской культуре). Москва: Ладомир, 2002.

Черепанова Ольга. Мифологическая лексика Русского Севера. Ленинград: Издательство Ленинградского университета, 1983.

Черепанова Ольга. „Кем „полохали“ детей на Руси“. Живая старина 1 (1994): 23-25.

Черепанова Ольга. Мифологические рассказы и легенды Русского Севера. Санкт-Петербург: Издательство Санкт-Петербургского университета, 1996.

Чеха Оксана. „Материалы по демонологии из села Линово“. Живая старина 3/47 (2005): $31-34$.

Bogišić Valtazar. Zbornik sadašnjih pravnih običaja u Južnih Slavena. Knj. I. Zagreb, 1874.

Božićević Juraj. „Narodni život u Šušnjevu selu i Čakovcu“. Zbornik za narodni život i običaje Južnih Slavena XI/1. Zagreb: JAZU, 1906.

Cvetek Marija. Naš voča so včas zapodval: bohinjske pravljice. Ljubljana: Kmečki glas (Glasovi 5), 1993.

Dulčić Jure. „Rječnik bruškoga govora“. Hrvatski dijalektološki zbornik. T. VII/2. Zagreb: JAZU, 1985.

Horvat Rudolf. „Narodna vjerovanja s bajanjem“. Zbornik za narodni život i običaje Južnih Slavena I. Zagreb: JAZU, 1896.

Hrobat Katja. „Ustno izročilo o kamenitih babah med etnologijo in arheologijo“. Čar izročila. Zapuščina Nika Kureta (1906-1995). Ljubljana, 2008: 407-425.

Ivančič Kutin Barbara. Krivopete: divje žene z nazaj zasukanimi stopali v slovenski folklori. Ljubljana: ZRC, 2018.

Jurančič Janko. Slovensko-srbskohrvatski slovar. Ljubljana: Državna založba Slovenije, 1981.

Jurić-Arambašić Ante. „Kijevo. Narodni život i tradicijska kultura“. Zbornik za narodni život i običaje Južnih Slavena 54. Zagreb: HAZU, 2000.

Keršovan N. Krebelj M. Düša na bicikli: Folklorne pripovedi iz Brkinov, doline Reke in okolice. Ljubljana: Kmečki glas (Glasovi 27), 2003.

Kelemina Jakob. Bajke in pripovedke slovenskega ljudstva z mitološkim uvodom. Bilje: Studio Ro, Založništvo Humar, 1997.

Kropej Monika. Od Ajda do zlatoroga. Slovenska bajeslovna bitja. Celovec - Ljubljana: Dunaj - Moharjeva, 2008.

Kure Bogomira. Zgodbe ne moreš iz žakla zvrnit. Folklorne pripovedi iz Bele krajine. Ljubljana: Kmečki glas (Glasovi 28), 2004.

Kuret Niko. Praznično leto Slovencev. Starosvetne šege in navade od podmladi do zime II, Ljubljana: Družina, 1998. 
Lang Milan. „Samobor. Narodni život i običaji“. Zbornik za narodni život i običaje Južnih Slavena XIX/2. Zagreb: JAZU, 1914.

Lovrenčević Zvonko. „Mitološke predaje Bilo-gore“. Narodna umjetnost 7 (1969-70): 71-100.

Majciger Janez. „Voda in njene moči v domišljiji štajerskih Slovcencev“. Kres III. Štev. 11. Celovec, 1883: 558-561.

Merkù Pavle. Ljudsko izročilo Slovencev v Italiji. Trst: Založba tržaškega tiska, 1976.

Milčetić Ivan. „Vjera u osobita bića. Otok Krk“. Zbornik za narodni život i običaje Južnih Slavena I. Zagreb: JAZU, 1896.

Nožinić Dražen. Etnografska građa iz Hrvatske (rukopis). Kardif, 1986-1989.

Peić Marko, Bačlija Grgo. Rečnik bačkih Bunjevaca, Novi Sad - Subotica: Matica srpska Subotičke novine, 1990.

Podgórscy Barbara i Adam. Wielka księga demonów polskich: leksykon i antologia demonologii ludowej. Katowice: KOS, 2005.

Primc Jože. Okameneli mož in druge zgodbe iz Zgornje Kolpske doline. Ljubljana: Kmečki glas (Glasovi 15), 1997.

Rešek Dušan. Brezglavjeki. Zgodbe iz Prekmurja. Ljubljana: Kmečki glas (Glasovi 9), 1995.

Težak Stjepko. „Ozaljski govor“. Hrvatski dijalektološki zbornik 5. Zagreb, 1981: 203-428.

Vukanović Tatomir. Srbi na Kosovu II. Vranje: Nova Jugoslavija, 1986.

Weiss Peter. Slovar govorov Zadrečke doline med Gornjim Gradom in Nazarjami. Pokusni svezek. Ljubljana: Založba ZRC, 1998.

\section{REFERENCES}

Amosova Svetlana, Gekht M. B. „Materialy ekspedicii k staroobryadcam g. Prejli (Latviya)“. Zhivaya starina 3/75 ( 2012).

Avilin Cimafej, Antropay̆ Mikalaj, Boganeva Alena. „Rusalki: zneshni vyglyad“. Belaruski fal'klor: materyyaly i dasledavanni. Zbornik. Vyp. 3. Minsk: Belaruskaya navuka, 2016: 222-273.

Babović Gliša. „Orolik. Istorija, život i običaji jednog sremskog sela“. Srpski etnografski zbornik LXXVI. Beograd 1963.

Belova Ol'ga. „Cygan“. Slavyanskie drevnosti. Etnolingvisticheskij slovar' pod obshchej redakciej N. I. Tolstogo. T. 5. Moskva: Mezhdunarodnye otnosheniya, 2012: 493-497.

Belova Ol'ga. „Mifologicheskie predstavleniya i pover'ya hutora Krymskij Ust'-Doneckogo rajona Rostovskoj oblasti“. Demonologiya i narodnye verovaniya. Sbornik nauchnyh statej. Moskva: GRCRF, 2016: 356-374.

BER. B"lgarski etimologichen rechnik I. Sofiya: BAN, 1971.

Bogišić Valtazar. Zbornik sadašnjih pravnih običaja u Južnih Slavena. Knj. I. Zagreb, 1874.

Bojanić Mihailo, Trivunac Rastislava. „Rečnik dubrovačkog govora“. Srpski dijalektološki zbornik XLIX. Beograd: SANU, 2002.

Boryak Olena. Ukraïna: etnokul'turna mozaïka. Kiïv: Libid', 2006.

Božićević Juraj. „Narodni život u Šušnjevu selu i Čakovcu“. Zbornik za narodni život i običaje Južnih Slavena XI/1. Zagreb: JAZU, 1906.

Bujskih Yuliya. „Personazhi detskih zapugivanij v sovremennyh predstavleniyah ukraincev v Poles'ya“. Zhivaya starina 1/81 (2014): 36-38.

Bukumirić Mileta. Rečnik govora severne Metohije. Knj. 15. Beograd: Institut za srpski jezik SANU, 2012.

Chekha Oksana. „Materialy po demonologii iz sela Linovo“. Zhivaya starina 3/47 (2005): 31-34.

Cherednikova Maina. „Golos detstva iz dal'nej dali..." (Igra, magiya, mif v detskoj kul'ture ). Moskva: Ladomir, 2002.

Cherepanova Ol'ga. Mifologicheskaya leksika Russkogo Severa. Leningrad: Izdatel'stvo Leningradskogo universiteta, 1983.

Cherepanova Ol'ga. „Kem „polohali“ detej na Rusi“. Zhivaya starina 1 (1994): 23-25.

Cherepanova Ol'ga. Mifologicheskie rasskazy i legendy Russkogo Severa. Sankt-Peterburg: Izdatel'stvo Sankt-Peterburgskogo universiteta, 1996.

Cvetek Marija. Naš voča so včas zapodval: bohinjske pravljice. Ljubljana: Kmečki glas (Glasovi 5): 1993. 
Cvijetić Ratomir. Rečnik užičkog govora. Beograd: Službeni glasnik, 2014.

Cyhun Genadz’. „Rusavy dzed“. Mifologiya belarusay̆, Minsk, 2011.

Dal' Vladimir. O poveriyah, sueveriyah i predrassudkah russkogo naroda. Sankt-Peterburg: Litera, 1996.

Dragović Đorđija. „Narodni običaji u Zagaraču“. Glasnik Etnografskog instituta SANU XLVI. Beograd: SANU, 1997: 195-220.

Drannikova Natal'ya, Razumova Irina. Mifologicheskie rasskazy Arhangel'skoj oblasti. Moskva: OGI, 2009.

Dukova Ute. Naimenovaniya demonov v bolgarskom yazyke. Moskva: Indrik, 2015.

Dulčić Jure. „Rječnik bruškoga govora“. Hrvatski dijalektološki zbornik. Zagreb: JAZU. T. VII/2, 1985.

Đorđević Dragutin. „Život i običaji narodni u Leskovačkoj Moravi“. Srpski etnografski zbornik LXX, Beograd: SANU, 1958.

Elezović Gliša. „Rečnik kosovsko-metohijskog dijalekta“. Knj. I. Srpski dijalektološki zbornik IV. Beograd, 1932.

Frezer Dzhejms Dzhordzh. Zolotaya vetv': Issledovanie magii i religii. Moskva: Politizdat,1980.

Gagović Svetozar. „Iz leksike Pive (selo Bezuje)“. Srpski dijalektoloshki zbornik LI. Beograd: SANU, 2004: 1-312.

Georgieva Ivanichka. B"lgarska narodna mitologiya. Vtoro preraboteno i dop"lneno izdanie. Sofiya: Nauka i izkustvo, 1993.

Gerov Najden. Rechnik na b"lgarskiya ezik I. Fototipno izdanie. Sofiya, 1975.

Golovin Valentin. Russkaya kolybel'naya pesnya v fol'klore i literature. Turku, 2000.

Grđić Bjelokosić Luka. „Narodno sujeverije“. Glasnik Zemaljskog muzeja VIII. Sarajevo: Zemaljska štamparija, 1896.

Grđić Bjelokosić Luka. Iz naroda i o narodu. Beograd: Prosveta, b.g.

Hafizova Larisa. „Buka kak personazh detskogo fol'klora“. Slavyanskij i balkanskij fol'klor: narodnaya demonologiya. Moskva: Institut slavyanovedeniya RAN, 2000, 198-211.

Hobzej Natalya. Gucul's'ka mifologiya: etnolingvistichnij slovnik. L'viv: Institut ukraïnoznavstva im. I. Krip'yakevicha NAN Ukraïni, 2002.

Horvat Rudolf. „Narodna vjerovanja s bajanjem“. Zbornik za narodni život i običaje Južnih Slavena I. Zagreb: JAZU, 1896.

Hrobat Katja. „Ustno izročilo o kamenitih babah med etnologijo in arheologijo“. Čar izročila. Zapuščina Nika Kureta (1906-1995). Ljubljana, 2008: 407-425.

Ivančič Kutin Barbara. Krivopete: divje žene z nazaj zasukanimi stopali v slovenski folklori. Ljubljana: ZRC, 2018.

Ivleva Larisa. Predstavleniya vostochnyh slavyan o nechistoj sile i kontaktah s nej. Materialy polevoj i arhivnoj kollekcii.... Sostavlenie V. D. Ken. Sankt-Peterburg: Peterburgskoe vostokovedenie (Ethnographica Petropolitana, XIII), 2004.

Jurančič Janko. Slovensko-srbskohrvatski slovar, Ljubljana: Državna založba Slovenije, 1981.

Jurić-Arambašić Ante. „Kijevo. Narodni život i tradicijska kultura“. Zbornik za narodni život i običaje Južnih Slavena 54, Zagreb: HAZU, 2000.

Karadžić Vuk. Srpski rječnik (1852) I-II, Beograd: Prosveta, 1986.

Kelemina Jakob. Bajke in pripovedke slovenskega ljudstva z mitološkim uvodom. Bilje: Studio Ro, Založništvo Humar, 1997.

Keršovan N. Krebelj M. Düša na bicikli: Folklorne pripovedi iz Brkinov, doline Reke in okolice. Ljubljana: Kmečki glas (Glasovi 27), 2003.

Klimchuk Fedor. „Duhovnaya kul'tura polesskogo sela Simonovichi“. Slavyanskij i balkanskij fol'klor. Etnolingvisticheskoe izuchenie Poles'ya. Moskva: Indrik, 1995: 335 -364.

Kolessa Filyaret. „Lyudovi viruvanya na Pidgiryu v s. Hodovichah Strijs'kogo povitu“. Etnografichnyj zbirnik. T. V. L'vov, 1898: 76-116.

Koprivica Jovan. Rečnik govora Banjana, Grahova i Oputnih Rudina. Priredio B. A. Koprivica. Knj. 47. Podgorica: Crnogorska akademija nauka i umjetnosti, 2006.

Korepova Klara, Hramova Natal'ya, Shevarenkova Yuliya. Mifologicheskie rasskazy i pover'ya Nizhegorodskogo Povolzh'ya. Sankt-Peterburg: Tropa Troyanova, 2007.

Kropej Monika. Od Ajda do zlatoroga. Slovenska bajeslovna bitja. Celovec — Ljubljana: Dunaj-Moharjeva, 2008. 
Kruglyasheva Vera (sost.). Predaniya i legendy Urala. Sverdlovsk: Sredne-Ural'skoe knizhnoe izd-vo, 1991.

Kure Bogomira. Zgodbe ne moreš iz žakla zvrnit. Folklorne pripovedi iz Bele krajine. Ljubljana: Kmečki glas (Glasovi 28), 2004.

Kuret Niko. Praznično leto Slovencev. Starosvetne šege in navade od podmladi do zime II. Ljubljana: Družina, 1998.

Lang Milan. „Samobor. Narodni život i običaji“. Zbornik za narodni život i običaje Južnih Slavena XIX/2. Zagreb: JAZU, 1914.

Leont'eva Tat'yana. „K izucheniyu semanticheskih svyazej mezhdu naimenovaniyami mifologicheskih personazhej i harakteristikami lyudej“. III Vserossijskij kongress fol'kloristov. T. 1. Aktual'nye problemy rossijskoj fol'kloristiki. Moskva: ROSKUL'TPROEKT, 2017.

Levkievskaya Elena. ,1) Demonologiya. Materialy k slovaryu polesskoj etnokul'turnoj leksiki; 2) Demonologiya severnorusskogo sela Tihman'gi“. Vostochnoslavyanskij etnolingvisticheskij sbornik. Issledovaniya i materialy. Moskva: Indrik, 2001: 379 -431, 432-476.

Lovrenčević Zvonko. „Mitološke predaje Bilo-gore“. Narodna umjetnost 7 (1969-70): 71-100.

Lyubova E. Yu. „Sistema mifologicheskih predstavlenij v govore P. Sarma Voznesenskogo rajona Nizhegorodskoj oblasti“. Vtorye Gromovskie chteniya. Russkie narodnye govory: proshloe i natoyashchee. Sbornik materialov i issledovanij. Kostroma: KGU im. N. A. Nekrasova, 2015.

Majciger Janez. „Voda in njene moči v domišljiji štajerskih Slovcencev“. Kres III Štev. 11. Celovec, 1883: 558-561.

Marković Blagoje. „Folkloristički zapisi iz Vrake“. Prilozi proučavanju jezika 17. Novi Sad: Filozofski fakultet, 1981.

Merkù Pavle. Ljudsko izročilo Slovencev v Italiji. Trst: Založba tržaškega tiska, 1976.

Mijatović Stanoje, Bušetić Todor. „Tehnički radovi Srba seljaka u Levču i Temniću“. Srpski etnografski zbornik XXXII, Beograd 1925.

Milčetić Ivan. „Vjera u osobita bića. Otok Krk“. Zbornik za narodni život i običaje Južnih Slavena I. Zagreb: JAZU, 1896.

Milosavljević Sava. „Srpski narodni običaji iz sreza homoljskog“. Srpski etnografski zbornik XIX, Beograd: SANU, 1914.

Moroz Andrej. Svyatye Russkogo Severa. Narodnaya agiografiya. Moskva: OGI, 2009.

Morozov Igor', Slepcova Irina. „Pugat'“. Tradicionnaya kul'tura Ul'yanovskogo Prisur'ya. Etnodialektnyj slovar'. T. 2. Moskva: Indrik, 2012: 419-430.

Naumenko Georgij. Etnografiya detstva. Sbornik fol'klornyh i etnograficheskih materialov. Belovod'e - Moskva: Rossijskij soyuz lyubitel'skih fol'klornyh ansamblej, 1998.

Nožinić Dražen. Etnografska građa iz Hrvatske (rukopis). Kardif, 1986-1989.

Peić Marko, Bačlija Grgo. Rečnik bačkih Bunjevaca, Novi Sad - Subotica: Matica srpska Subotičke novine, 1990.

Petrović Petar. „O bauku“. Glasnik Etnografskog muzeja VIII. Beograd: Etnografski muzej, 1933: 104-107.

Plotnikova Anna. „Mifologicheskaya leksika serbsko-bolgarskogo pogranich’ya“. Issledovaniya po slavyanskoj dialektologii 10. Moskva 2004: Institut slavyanovedeniya RAN.

Podyukov Ivan i dr. Slovar' russkih govorov Yuzhnogo Prikam'ya. Vyp. II. Perm': Izdatel'stvo PGGPU, 2010.

Podgórscy Barbara i Adam. Wielka księga demonów polskich: leksykon i antologia demonologii ludowej. Katowice: KOS, 2005.

Primc Jože. Okameneli mož in druge zgodbe iz Zgornje Kolpske doline. Ljubljana: Kmečki glas (Glasovi 15), 1997.

Radan Mihaj. „Karashevska mitoloshka i demonoloshka leksika“. U pohode tajnovitom Karashu. Temishvar, 2002: $139-158$.

Radenković Ljubinko. „Strašila za decu — neke slovenske paralele“. Zhizneniyat cik”l. Dokladi ot b"lgaro-sr" bska nauchna konferenciya. Sofiya: Etnografski institut s muzej, 2000: $146-155$.

Rešek Dušan. Brezglavjeki. Zgodbe iz Prekmurja. Ljubljana: Kmečki glas (Glasovi 9), 1995.

RMJ. Rečnik na makedonskiot jazik so srpskohrvatski tolkuvanja. Redaktor Blazhe Koneski, Skopje: Makedonska kniga, 1986.

Romanov Evdokim. Belorusskij sbornik. Byt belorussa. T. VIII. Vil'na: Tipografiya A. G. Syrkina, 1912. 
RSANU. Rečnik srpskohrvatskog književnog i narodnog jezika I-XXI, Beograd: SANU, 19592020.

RSGV. Rečnik srpskih govora Vojvodine 1-10, Novi Sad: Matica srpska, 2000-2010.

Sedakova Irina. „Etnolingvisticheskie materialy iz severo-vostochnoj Bolgarii (s. Ravna, Varnenskaya obl.)“. Issledovaniya po slavyanskoj dialektologii 10. Moskva: Institut slavyanovedeniya RAN, 2004.

Sinica N. A. „Leksika narodnoj demonologii Pavinskogo rajona“. Zhivaya starina 3/67 (2010): $43-46$.

Sinica N. A. „Demonicheskaya leksika Nikol’skogo rajona Vologodskoj oblasti““. Zhivaya starina 3/83 (2014): 55-58.

Smol'nikov S. N. „Demonologicheskie predstavleniya v Vashkinskom r-ne Vologodskoj oblasti“. Zhivaya starina 1/9 (1996): 50-51.

Stojanović Radosav. „Crnotravski rečnik“. Srpski dijalektološki zbornik LVII, Beograd, 2010.

Stojkov Stojko. Leksikata na banatskiya govor, s banatsko-b”'lgarski rechnik. Sofiya: BAN, 1968.

Syatkovskij Yanush. „Slavyanskie nazvaniya strashilishch (demonov) v nemeckom yazyke i ego govorah". Slovo i kul'tura. Pamyati Nikity Il'icha Tolstogo. T. I. Moskva: Indrik, 1998: 280-287.

Težak Stjepko. „Ozaljski govor“. Hrvatski dijalektološki zbornik 5. Zagreb, 1981: 203-428.

Trefilova Ol'ga. „Etnolingvisticheskie materialy iz s. Stakevcy, rajon g. Belogradchika (SeveroZapadnaya Bolgariya)“. Issledovaniya po slavyanskoj dialektologii 10. Moskva: Institut slavyanovedeniya RAN, 2004: 354-398.

Trefilova Ol'ga. „Narodnaya mifologiya iz Tvyrdicy (Bolgariya, Verhnyaya Frakiya)“. Karpatobalkanskij dialektnyj landshaft. Yazyk i kul'tura 2. Moskva: Institut slavyanovedeniya RAN, 2012: 270-285.

Uzeneva Elena. „Etnolingvisticheskie materialy iz central'noj Bolgarii (selo Dylboki, oblast' Staroj Zagory)“. Issledovaniya po slavyanskoj dialektologii 10. Moskva: Institut slavyanovedeniya RAN, 2004: 268-297.

Valencova Marina M. „Perhta“. Slavyanskie drevnosti. Etnolingvisticheskij slovar’ pod redakciej N. I. Tolstogo. T. 4. Moskva: Mezhdunarodnye otnosheniya, 2009: 18-20.

Valencova Marina. Narodnyj kalendar' chekhov i slovakov. Etnolingvisticheskij aspekt. Moskva: Indrik, 2019.

Valencova Marina. „Moravskaya i silezkaya demonologiya v cheshsko-slovackom kul'turnom areale“. Slavica Slovaca 52/2 (2017): 122-132.

Valencova Marina. „Moravskaya demonologicheskaya leksika“. Slavyanskij al'manah 1-2. Moskva: Indrik, 2018: 234-260.

Valodzina Tacyana. „Golobaba“. Mifalogiya belarusay̆. Encyklapedychny sloy̆nik, Minsk, 2011.

Vinogradov Georgij S. Etnografiya detstva i russkaya narodnaya kul'tura v Sibiri. Moskva: Vostochnaya literatura RAN, 2009.

Vinogradova Lyudmila, Levkievskaya Elena. Narodnaya demonologiya Poles'ya. Publikaciii tekstov v zapisyah 80-90-ih gg. XX veka. T. II. Moskva: Yazyki russkoj kul'tury, 2012.

Vlasova Marina. Russkie sueveriya. Enciklopedicheskij slovar'. Sankt-Peterburg: Azbuka, 1998. Vlasova Marina, Zhekulina Valentina. Tradicionnyj fol'klor Novgorodskoj oblasti: skazki, legendy, predaniya, bylichki, zagovory (po zapisyam 1963-1999). Vyp. II. Sankt-Peterburg: Aletejya, 2001.

Vostrikov Oleg. Tradicionnaya. kul'tura Urala: etnoideograficheskij slovar' russkih govorov Sverdlovskoj oblasti. Vyp. 1-5,. Ekaterinburg: Sverdlovskij oblastnoj Dom fol'klora, 2000.

Vukanović Tatomir. Srbi na Kosovu II. Vranje: Nova Jugoslavija, 1986.

Vukanović Tatomir. Enciklopedija narodnog života, običaja i verovanja u Srba na Kosovu i Metohiji. Beograd: Vojnoizdavački zavod - VERZALpress, 2001.

Weiss Peter. Slovar govorov Zadrečke doline med Gornjim Gradom in Nazarjami. Pokusni svezek. Ljubljana: Založba ZRC, 1998.

Zajceva Natal'ya. Mifologicheskaya leksika v cheshskom i slovackom yazykah. Dissertaciya. Minsk: Belorusskij univesitet, 1975.

Zlatanović Momčilo. Rečnik govora južne Srbije. Vranje: Učiteljski fakultet, 1998.

Zlatković Dragoljub. „Frazeologija straha i nade u pirotskom kraju“. Srpski dijalektološki zbornik XXXV. Beograd: SANU, 1989. 
Ljubinko Radenković

\section{SLAVIC MYTHOLOGICAL CHARACTERS FOR FRIGHTENING CHILDREN}

\section{Summary}

The traditional raising of children among the Slavic peoples actively utilized frightening - among other things using mythological characters. These characters, unlike mythological beings, have minimal features. Most commonly their appearance is undefined and is not indicative of where they live and when they are active. The image is created that they are always near the child and always prepared to punish it if it is disobedient. According to this study, the language and folklore of the Slavic people contains no less than 200 such characters. In this function, on one hand, they overlap with certain animals (most commonly the bear, wolf and bugs) and foreigners (Gypries, Turks, Tatars), and on the other with mythological beings (rusalka, vodyanoy, house spirit, devil). An overview of the names of mythological beings used to frighten children in Slavic languages, take from folklore and lexical sources, shows that the only commonalities are the names formed using the base *ba-/*bo-/*bu-, or root *bab-, *bob-, *bub-. All the others have a more or less regional distribution. Also common are the predicates, which convey the menacing activity of the mythological characters, aimed at the child, if it is disobedient, such as: catch, drag away, eat.

In addition to its function of pacifying children, frightening represents one of the cultural mechanisms that at an early age impose on children the semantics of space and time, as well as desirable forms of social conduct.

Key words: fear, children, mythological characters, lexicology, Slavic folk culture. 